\title{
Dealing with Bank System Failure: Indonesia, 1997-2002
}

\author{
Ross H. McLeod \\ Indonesia Project, Economics Division \\ The Australian National University \\ $\underline{\text { Ross.McLeod@anu.edu.au }}$
}

\begin{abstract}
The crisis recovery program in Indonesia has failed badly in relation to the two key objectives of development economics policy-making: efficiency and equity. The economy went into a very severe recession within a few months of the IMF appearing on the scene, and five years later output was still only at approximately the pre-crisis level. The collapse of the banking system and the associated bailout of depositors by the government has had the effect of imposing a loss on the general public, and the poor in particular, of the order of $40 \%$ of GDP. This paper describes the collapse of the banking system and the policies the government has followed in response to it, under advice from the IMF. It then goes on to propose an alternative scheme that might have been followed-and that could be followed in future banking crises - the twin objectives of which are to maintain the integrity of the payments system while avoiding inequitable wealth transfers that result from government bailouts of banks and their depositors.
\end{abstract}

JEL classification codes: E42, E58, E65, G21, G28

Keywords: banking crisis, lender of last resort, deposit guarantee, payments system. 


\section{Dealing with Bank System Failure: Indonesia, 1997-2002}

\section{INTRODUCTION}

The collapse of the Thai baht in July 1997 provided the trigger for a re-evaluation by investors of the exchange rate risks of holding assets in Indonesia, and of the potential for profit from the acquisition of assets elsewhere. Immediately, the central bank found itself rapidly losing reserves in an attempt to prevent depreciation of the rupiah, and within about six weeks the government decided to float the currency. This abrupt policy shift had the effect of prompting many more investors to reevaluate and rebalance their portfolios. The resulting large depreciation of the rupiah caught most by surprise, and caused many corporate borrowers that had taken dollar-denominated loans - including large amounts from domestic banks - to default on their loan repayments.

To ward off bank failures the central bank began operating as lender of last resortbefore long on very large scale - but its failure to sterilise the monetary impact of its actions meant that it was supplying the liquidity needed by all those investors who wanted to purchase foreign currency, either to unwind their exchange rate risk exposure or to speculate against the rupiah (McLeod 2002). The upheaval in the foreign exchange market came to be so great that the IMF was called upon for assistance and, as a condition of this support, the government had to accept a number of policy reforms that amounted to direct attacks on the president through his family and cronies. ${ }^{1}$ Arguably this sent a message to the investment community that the ageing President Soeharto, Indonesia's extraordinarily powerful ruler for over three decades, was beginning to lose his grip - an assessment that was greatly strengthened when he became ill around late November 1997 and, for the first time ever, had to cancel a planned overseas trip.

A series of other issues heightened investors' concerns even further in the following months. A budget was introduced in January 1998 that went against the IMF's desire to see a significant surplus, and contained obviously unrealistic assumptions in

\footnotetext{
${ }^{1}$ These included: reductions in tariff protection in certain sectors; reduced spending on infrastructure projects; removal of many restrictions on direct foreign investment; tighter controls on procurement and contracting procedures; accelerated implementation of the ruling of the WTO dispute panel on the National Car project; the phasing out of a number of import and marketing monopolies; closure of a number of private banks (some controlled by members of the Soeharto extended family); and privatisation of state banks that had previously lent heavily to companies favoured by the president. For a discussion of the politico-economic system under Soeharto, focusing on how economic policy was used to enrich the first family and its business associates and to entrench Soeharto's hold on power, see McLeod (2000a and 2000b).
} 
relation to several key macroeconomic variables (Soesastro and Basri 1998: 21). Soon afterward the president made it clear that he was intending to take his Minister for Research and Technology, BJ Habibie, as his vice-president for the coming five year period, whereas it was clear that the IMF wanted Habibie's influence curtailed. ${ }^{2}$ And when forming his new cabinet in March 1998, Soeharto again thumbed his nose at the IMF's intention to deal a blow to 'KKN' (corruption, collusion and nepotism) by appointing one of his daughters and one of his closest cronies to ministerial positions (Johnson 1998: 5-6).

Eventually the unexpected and severe deterioration of the macroeconomic environment weakened the president's hold on power so greatly that he was forced to resign in May 1998. Within a few months the currency had appreciated strongly and inflation began to fall rapidly (McLeod 2002). The economy was in deep recession, but output began to stabilise within about six months of Soeharto's departure; nevertheless the debris of the economic and banking collapse was still far from being cleared away by late 2002 .

\section{A simple analysis of the crisis}

The story of Indonesia's economic implosion in 1997-98 can be summarised quite simply for analytical purposes (Figure 1). The perceived risk of holding assets in Indonesia increased for a variety of reasons such as those just discussed. This meant that a higher return on new investment (and existing assets) was required in order to offset the now higher perceived risk. In Figure 1 the supply curve of foreign savings (assumed perfectly elastic for simplicity) shifts up by an amount $\delta$, the increase in the risk premium required to attract funds to Indonesia; the volume of investment falls as a result. The supply curve of domestic savings is assumed to shift up by a similar amount, which implies that the volume of domestic savings is unchanged. Capital inflow - the difference between the level of domestic investment and the level of domestic savings at the world interest rate-becomes negative, falling from $K_{0}$ to $K_{1}$. Domestic savers earn an ex ante rate of return $w+\delta$ if they invest in Indonesia, or $w$ if they place their savings offshore. The expected ex post rate of return is $w$ in either case. An important implication of all this is that values of existing assets in Indonesia decline, on average, relative to those in the rest of the world, in order that asset yields will rise to cover the new, higher risk premium.

\footnotetext{
2 The January 1998 LOI reported that it had been decided to discontinue immediately any budgetary and extra-budgetary support and credit privileges granted to projects of the state aircraft manufacturer, IPTN, headed by Habibie.
} 


\section{Figure 1: Response of Capital Inflow to Increased Perceived Investment Risk}

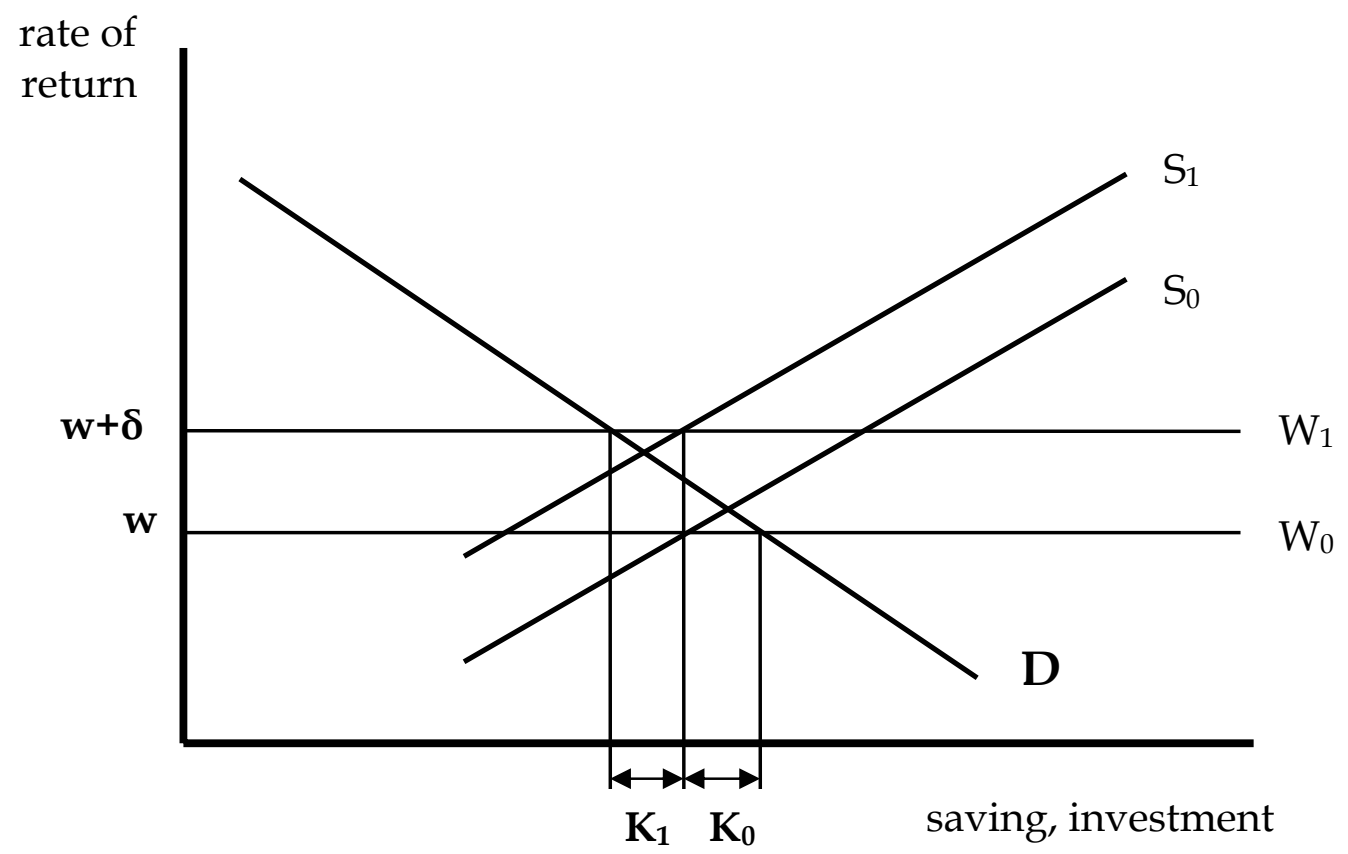

The reduction (or turnaround) in capital inflow requires depreciation of the real exchange rate if equilibrium is to be re-established, in exactly the same way that a decline in a country's terms of trade does. Unfortunately neither the government nor the IMF saw things in this way, as a result of which a series of ill-conceived policies were implemented with the intention of 'saving the rupiah'. These policies ignored the need for structural readjustment implied by the change in Indonesia's circumstances, and tried to prevent the real exchange rate depreciation that would drive this readjustment from occurring. At first a severe liquidity squeeze was imposed, in the hope that higher interest rates would halt the capital outflow that seemed to be weakening the rupiah. ${ }^{3}$ Soon thereafter the government began to implement a fiscal contraction by cancelling or postponing a range of large infrastructure projects, and later by increasing some taxes and reducing various subsidies. ${ }^{4}$ The result of this was simply to exacerbate the reduction in private sector spending that was already occurring as a consequence of the heightened assessment of risk on the part of businesses, consumers and importers in Indonesia's trading

3 This view confused the symptom (capital outflow) with the cause (the negative reassessment of risk).

${ }^{4}$ McLeod (1997: 103) warned of the danger to the economy of these inappropriate responses by the government to the sudden depreciation of the rupiah. 
partners. The rupiah depreciated in real terms nevertheless, notwithstanding a burst of high domestic inflation in early 1998.

McKibbin (1998) provides an analysis of the impact of heightened risk perceptions concerning the Asian crisis countries in a global general equilibrium framework. An important difference from the present analysis is his assumption that the risk shock is temporary, and dies away progressively over about three years. This is analogous to assuming that a terms of trade shock (say, arising from a sudden decline in the world price of one of a country's main exports) is a temporary 'blip' rather than a long-lasting change that is as likely to be amplified as to wither away. Taking the real exchange rate as indicator, there seems little doubt that investors still perceive risks in the Asian crisis countries to be considerably greater than they did prior to the crisis. By mid 2002 the depreciation of Indonesia's real exchange rate, approximated by the nominal exchange rate divided by the consumer price index, had settled at about $50 \%$. By comparison, this measure of real depreciation was $37 \%$ in Malaysia, 34\% in Thailand, and 18\% in Korea (McLeod 2002).

\section{COLLAPSE OF THE BANKING SYSTEM}

The massive collapse of the banking sector has been perhaps the most extraordinary aspect of Indonesia's crisis, and provides the main focus for this paper. The outcome, at least as seen in late 2002, is vastly different from that envisaged in the initial Letter of Intent (LOI) from the government to the IMF, ${ }^{5}$ when banking problems were seen as relatively minor. Then, it was thought they could be overcome simply by closing down a few of the worst banks, nursing other troubled banks back to good health, and privatising all the banks owned by the national and provincial governments. Moreover, by strengthening the legal and regulatory environment such problems could be avoided in the future. Five years later, scores of banks had been closed down; many more remained dependent on a government guarantee of banks' liabilities; no government banks had been privatised; and the key prudential regulation relating to capital adequacy had been relaxed rather than strengthened. More important, perhaps, the general public has been left burdened by a debt

5 This paper makes frequent references to the series of LOIs. All may be found at the Indonesia section of the IMF web site: http://www.imf.org/external/country/idn/index.htm?type=9998\#23. They are identified here by the date (month and year) they were sent. 
amounting to at least $40 \%$ of GDP as a result of the way the impact of the crisis on the banking system was handled. ${ }^{6}$

The initial LOI in October 1997 estimated the volume of non-performing loans in the banking system at about $8 \%$, although it cautioned that the number could be somewhat higher because of measurement problems. This estimate seems ludicrously low in retrospect, but it should not be assumed that all of the nonperforming loans that came to light during the crisis had existed when it began. Perhaps the majority of these bad loans were generated subsequently, as the owners of many companies seized the opportunity to take advantage of the high level of corruption in the legal system by defaulting on loans from the banking system. In so doing they felt secure in the knowledge they could bribe prosecutors, judges and other legal officials to keep their major creditor-the government, by virtue of having virtually taken over the banking system-at bay. The process has been facilitated and greatly encouraged by the provision of grossly excessive lender of last resort loans by the central bank and, later, by poor implementation of policies relating to a blanket guarantee of banks' liabilities provided by the government.

The first LOI gives the impression that the policy makers had the problem firmly in hand:

Insolvent banks have been closed and weak, but viable, institutions have been required to formulate and implement rehabilitation plans. At the same time, steps are being taken to minimize future systemic risks. In particular, the legal and regulatory environment will be strengthened by establishing strong enforcement mechanisms and introducing a stringent exit policy.

The government is convinced that this program ... will restore soundness of the financial system and its ability to intermediate funds efficiently.

The strategy involved four elements. First, some 16 small, unviable banks had their licences revoked and were closed; the owners lost all of their equity investment, but deposits of up to Rp 20 million (about \$US5,600 at the time) were to be guaranteed by the government. Once the banking system had returned to good health, an explicit deposit insurance scheme was to be introduced. This would be designed to minimise moral hazard and to protect deposits up to a specified amount.

\footnotetext{
${ }^{6}$ For a detailed discussion of the impact of the crisis on the banking sector and the estimated cost to the government, see Fane and McLeod (2002).
} 
Second, proper procedures and policies were to be established to enable the authorities to deal promptly with weak but viable financial institutions so that they could be placed quickly on the road to recovery; if these banks' rehabilitation plans did not adequately demonstrate a quick return to financial viability, they would be closed. Some 10 banks had already agreed to submit such plans, and faced closure by the end of 1998 if they had not succeeded in obtaining sufficient injections of new equity. In the meantime, they had been provided with subordinated loans ${ }^{7}$ from Bank Indonesia to keep them going.

Third, in relation to the government-owned banks, mergers and 'other strategic tools' were to be used to maximise debt recovery, to improve corporate governance, and to ensure that the banks benefited from increased private ownership and increased participation of private owners in their governance. A plan for accelerated privatisation of the state banks was to be drawn up during the first year of the program, and recapitalisation was to be used only in conjunction with concurrent privatisation. Since this paper is primarily concerned with how the government has tried to deal with the problem of private sector banks during the crisis, it will not deal further with this aspect. Suffice it to say that in fact there have been huge injections of equity by the government to recapitalise the state-owned banks, and that no privatisations had occurred at the time of writing.

Finally, it was intended to improve the institutional, legal, and regulatory framework for banking. For example, the laws and decrees governing the central bank and commercial banking operations were to be revised to incorporate international best practice, and regulations concerning foreign ownership of financial institutions were to be modified to facilitate entry of international banks and investors. Prudential regulations and enforcement procedures were also to be strengthened, and the previous intention to raise the minimum acceptable capital adequacy ratio to $9 \%$ by the end of 1997 and to $12 \%$ by the end of 2001 was to be 'strictly enforced'.

\section{Lender of last resort activities}

Various other details of the overall strategy are worth mentioning. For example, there is an indication that Bank Indonesia's lender of last resort activities hitherto left something to be desired. Henceforth, loans to illiquid but solvent banks were to be collateralised and extended to individual institutions at increasingly punitive

\footnotetext{
7 Subordinated loans rank above shareholders' equity, but below all other liability categories, in the case of bankruptcy.
} 
interest rates, and any emergency assistance to banks to deal with systemic risks was to be explicitly guaranteed by the government. Bank Indonesia was to develop rules for the Jakarta Clearing House that would transfer settlement risk ${ }^{8}$ from Bank Indonesia to participants within six months. Another interesting aspect is a reference to the need to develop the domestic bond market in order to provide an alternative to the banks for funding long-term debt requirements in foreign currencies.

By the time of the second (January 1998) LOI, it was clear that things were not going as well as had been hoped:

... the continued depreciation of the rupiah, the slowdown in growth, and high interest rates ... have led to a marked deterioration of the financial condition of the remaining banks. This deterioration has been exacerbated by deposit runs and capital flight, forcing many banks to increasingly resort to central bank liquidity support. The large depreciation of the rupiah in recent weeks has raised the concern that these problems will only intensify.

The emphasis now was on establishing rules for resolving liquidity and solvency problems of the private banks. Bank Indonesia was to provide liquidity support to banks subject to increasingly stringent conditions, 9 'while ensuring that liquidity support was consistent with the program's monetary growth objectives'. This it failed to do: the scale of lending was so great as to cause base money to grow by no less than $30 \%$ in the next six months, given the failure properly to sterilise its monetary impact. Ultimately Bank Indonesia was to lend some Rp 145 trillion (in rough terms, \$US15 billion) to the banks through a variety of mechanisms (BPK 2000). Surprisingly, the LOI did not draw attention to the interconnectedness of heavy lending to the banks by the central bank and strong speculation against the rupiah-which, in turn further weakened the banking system, leading to new requests for additional support.

\footnotetext{
8 This refers to the risk that cheques drawn on one bank and payable to another might not clear because of a deficiency of funds in the paying bank's account at the central bank. It appears that in late 1997 and early 1998 this risk was being carried by Bank Indonesia, rather than being borne by the recipient bank.

${ }^{9}$ Imposing high interest rates on last resort loans is rather pointless if the banks are already insolvent. The banks' owners have nothing more to lose, and will therefore be happy to take expensive loans in order to get the chance to 'gamble on redemption'. Perhaps, therefore, the intention was to require banks' owners to put up better collateral for their banks' borrowings.
} 
The LOI also foreshadowed the establishment of a financial institution that was later to materialise as the Indonesian Bank Restructuring Agency (IBRA), but at this stage its intended function was only to take over the non-performing loans of the state banks. The government's commitment to stronger enforcement of prudential regulations, and to strengthening those regulations, was also reiterated.

\section{Blanket guarantee of bank liabilities}

The third LOI (April 1998) drew attention to the importance of putting a stop to last resort lending in order to bring money growth under control. The chosen means of achieving this was to substitute a government guarantee of banks' liabilities for last resort loans. Alternatively, it would have been possible to sterilise the monetary impact of last resort lending simply by issuing a similar amount of SBIs (McLeod 2002). Enoch et al. (2003) assert that the authorities [were] unable to sterilise the impact on overall liquidity conditions, [because of] both the lack of effective instruments of monetary control at the time and the authorities' concerns over the impact of high interest rates on the banks ...' On the contrary, however, SBIs were a perfectly adequate instrument for this purpose, and using them would not have placed upward pressure on interest rates, since this would not have reduced liquidity but merely stopped it from expanding.

The LOI noted that a mere seven banks accounted for the bulk of last resort loans to the banking system, thus making it important for the newly established IBRA to take over these (mostly private sector) banks in order to try to safeguard the government's exposure to them. Nevertheless, the LOI also implicitly recognised the danger of concentrating so much of the banking system in one government-owned holding company:

... steps are being taken to strengthen IBRA and ensure that it has the resources and independence to complete the restructuring of the banking system effectively and to maintain the highest standards of governance.

It was reported that Bank Indonesia was intensifying its efforts to rehabilitate and strengthen healthier banks, including raising their capital adequacy levels to international standards. The total cost to the government of reimbursing Bank Indonesia for its liquidity support, covering the guarantee of banks' liabilities, and restoring capital adequacy ratios to $8 \%$ was estimated at $15 \%$ of GDP, but it was argued that the ultimate cost would be less than this because the government would be able to sell off the equity stake it was temporarily acquiring in the private sector banks. 
Although the cost to the government of bank restructuring was to be recorded transparently in the budget, this commitment can be interpreted in different ways. It would appear that the IMF's interpretation was that only the interest costs of servicing the recapitalisation bonds would be recorded. ${ }^{10}$ This interpretation allowed the LOI to project the budgetary cost of bank restructuring in 1998/99 at about 1 percent of GDP, which seemed significant but not intolerable. By contrast, if a government building had fallen down and had to be rebuilt, what would be recorded in the budget would be the cost of rebuilding, not the interest on the principal amount involved. If the cost of the bank bailout had been interpreted in the same way, the general public would have gained a much more realistic view of the size of the financial disaster that was unfolding.

\section{Softening the capital adequacy standards}

The October 1998 LOI provides the first indication that, despite the previously expressed intention to strengthen prudential standards for the banking system, the policy makers were so keen to minimise the number of further bank closures that they decided instead to soften the most fundamentally important of those standards: namely, the minimum acceptable capital adequacy ratio (CAR). The near-term target was now set at $4 \%$, rather than $9 \%$-the standard originally to be achieved by September 1997. There was no explicit mention of the fact that the minimum standard had been so drastically lowered, much less any attempt to justify this decision. ${ }^{11}$

At the same time, the government's strategy for restructuring weak but viable banks was clarified. It is noteworthy that the principal criterion for classifying a bank as weak but viable was backward looking: the bank's capital adequacy ratio-which can be thought of as a summary measure of the consequences of what it had done in the past-had to be between $-25 \%$ and $4 \% .12$ The alternative would have been to evaluate banks' prospects for the future, regardless of their present capital adequacy position - bearing in mind that, as guarantor of the banks' liabilities, the government

\footnotetext{
10 'With the [interest] cost assumed on the budget, it is demonstrated transparently with other elements of public expenditure ...' (Enoch et al. 2003).

11 This new CAR requirement was relaxed even further in June 2000 by allowing banks to include their loan loss reserves in measured capital (Jakarta Post, 16 June 2000), despite the fact that loss reserves are an estimate of losses the banks expect to incur-whereas 'capital' for the purpose of calculating the CAR is supposed to be available to meet unexpected future losses.

12 Banks with CARs below $-25 \%$ were to be closed; those above $4 \%$ needed no further immediate action.
} 
was obliged to make good each bank's equity deficiency, regardless of whether it was closed or resurrected.

The fourth LOI (June 1998) reported that the condition of banks had deteriorated further. Dealing with the banking system was being given the highest priority, because this was regarded as an essential precondition for the recovery of the corporate sector. In retrospect, however, this view can be seen to be superficial. After all, the banks had failed because the corporate sector had failed to repay its loans to them. Even if the banks' capital could now be restored, it is difficult to understand how they could have simply resumed lending to the corporate sector when it remained heavily in default to them. The only way that this could have made any sense would be if the banks were prepared to forgive non-repayment of loans they had previously issued, taking the implied losses on to their own books and, in effect, passing the losses on to the government as guarantor of their liabilities.

\section{Bank recapitalisation}

A key focus was on measures to strengthen relatively sound banks - partly through the infusion of new capital - whereas the intention with weak banks was to move swiftly merge or close them if they could not be recapitalised. The July 1998 LOI reported that some 13 private banks had been taken over by IBRA, and that negotiations were underway with buyers interested in acquiring some of these banks as going concerns. The government intended to complete the restructuring of the six large banks taken over in April 'in the next few weeks'. Moreover, discussions were already underway with the main shareholders of several large private banks that had passed into IBRA's control to secure the repayment of liquidity support that had been provided by Bank Indonesia.

The September 1998 LOI referred to the August announcement of a major bank restructuring package covering banks accounting for almost half of banking system assets; by contrast, it may be recalled that in the first LOI, 16 small banks had been closed, and the government expressed its confidence in other measures it was initiating to deal with problems in the banking sector. The LOI reiterated the government's intention quickly to complete negotiations with the former owners of large banks regarding repayment of Bank Indonesia liquidity support; similar statements can be found in almost all subsequent LOIs, ${ }^{13}$ but there is very little

\footnotetext{
13 For example, in the October 1998 LOI it was stated that 'negotiations with other former bank owners [were] expected to yield appropriate settlements in coming weeks'.
} 
evidence to suggest that these negotiations have been successful from the government's point of view. In the March 1999 LOI there is an early indication of lack of progress in recovering funds from the owners of banks that had obtained extensive liquidity support and had been engaged in large-scale connected lending (i.e. lending to affiliates). This was followed by a threat, often to be repeated later, that the government would take strong legal action against recalcitrants. ${ }^{14}$

Further details of the strategy for recapitalising weak but viable banks were provided in the November 1998 LOI. The government's contribution to the recapitalisation $(100 \%$ in the case of banks taken over, and up to $80 \%$ for banks that were being jointly recapitalised with their original owners) was to be in the form of long-term bonds, including both market-linked and indexed bonds. ${ }^{15}$ It may be noted in passing that having the government 'contribute funds to recapitalise banks' is a euphemism for transferring accumulated bank losses (in excess of shareholders' funds) to the general public, rather than to the banks' depositors and other creditors. It is also interesting to note that an explicit objective to ensure that the banking system was restructured at minimum cost to the public did not appear until the January 2001 LOI. Since the amounts of these losses have turned out to be enormous, and since the vast bulk of Indonesia's poor do not own bank deposits, this has turned out to be an extraordinarily inequitable policy choice. We shall revisit this issue later.

Given the choice of having the government recapitalise the banks, there was no discussion of the alternative strategy for doing so under which the government would simply provide a cash injection, the monetary impact of which could have been sterilised by issuing an equivalent volume of bonds in the market.16 Presumably this strategy was not chosen because the government feared that the interest rate necessary to issue such bonds would have been relatively high, with obvious implications for the fiscal burden of servicing them; injecting these bonds directly into the portfolios of the banks in question allowed the policy makers to set the interest rate at a level they considered appropriate. Given the IMF's strong

\footnotetext{
14 '... on March 7 the government decided on a strategy to resolve the long-standing problem of shareholder settlement agreements with former bank owners that have fallen into dispute and/or default' (April 2002 LOI).

${ }^{15}$ In the event, fixed and floating rate bonds were issued to recapitalise the banks.

${ }^{16}$ Nor was there any discussion of the rationale for the decision to issue both fixed and floating rate bonds or of the means by which the relative amounts were determined.
} 
predilection for market solutions, it is surprising that this strategy was adopted. The unfortunate consequence was that the true value of the recapitalisation bonds was well below their face value, because the bonds carried artificial, below-market interest rates.

\section{Not the new era in prudential regulation transparency}

The January 2000 LOI contained further interesting discussion of this issue. It was reported that since December 1999 the banks had been permitted to transfer up to 10 percent of their bonds into a 'trading portfolio', and that, from February 2000, they would be permitted to trade these bonds in the secondary market. The portion of bonds in the trading portfolio would thereafter be increased progressively. This raises the obvious question: why were banks not permitted to trade these bonds in their entirety as soon as they received them? After all, the government strongly desired that the banks would recommence lending to the corporate sector, which would have required them to divest the bonds from their portfolios to provide the funds needed to make new loans. The answer, presumably, was that this would have revealed their true value - which, in turn, would have revealed the fact that the banks had not actually been recapitalised to even the precariously low $4 \%$ capital adequacy ratio. One of the eventual consequences was that bids received when banks were to be re-privatised were considerably below book value, making it politically difficult for the government to proceed with such sales.

Bank Indonesia, as the prudential regulator - which recently had been putting great emphasis on rewriting the prudential regulations in order to force banks to make much more realistic provisions for loan losses ${ }^{17}$ - was now in the position of turning a blind eye to the deliberate overstatement of the value of the bonds in the banks' portfolios (McLeod 2000c: 29). Once some of these bonds were traded in the market their true value became obvious, and this resulted in a rather farcical accounting treatment of them. The proportion of bonds arbitrarily designated as being held for trading purposes was valued at market prices. The identical remainder of the bonds were designated as being held until maturity, and continued to be booked at their considerably higher face value!

17 That is, to ensure that loans are carried in the books so as to reflect the best estimate of their true value, after taking into consideration the probability of default. 


\section{Picking and choosing}

It was noted also that seven private banks that did not qualify for the recapitalisation program had been kept open 'in the public interest', in light of their large depositor base (over 80,000 accounts, accounting for $2.5 \%$ of bank deposits) and to minimise the disruption of banking services. There was some scepticism at the time as to whether the real reason might have had something to do with political pressure from the owners, but the LOI reported that the owners' rights had 'effectively been fully revoked'. Taking this assertion at face value, it is worth asking why the same approach was not taken with all of the banks. Others that also had many thousands of deposit customers were simply closed, regardless of the disruption of banking services - not to mention the loss of jobs - that this caused. It seemed almost as if the authorities wanted to punish certain banks, which would be absurd. If there were to be any penalties they should have been imposed on the banks' owners: the first step would have been to cancel their shares in the banks, as was done with these seven special cases. The owners could also have been prosecuted for breaches of various prudential regulations - in particular, those relating to limits on lending to affiliated companies. ${ }^{18}$

\section{The negative spread problem}

An interesting new issue emerged in the May 1999 LOI in relation to bank restructuring. A significant concern had arisen in relation to the banking system in relation to profitability. Specifically, there was a problem of 'negative interest spread'-that is, interest costs were exceeding interest revenues. An important contributing factor here was the government guarantee of bank liabilities-in particular, deposits. By way of explanation: when the safety of deposits is guaranteed by the government, there is an incentive for bank managers to offer relatively high rates of interest on deposits so as to collect a large volume of funds that can be used for purposes that may involve a high element of risk. To limit this moral hazard problem, the government imposed a ceiling on the interest rate that could be offered for guaranteed deposits.

This ceiling was set at quite a high rate-appreciably higher than the rate at which the banks could lend the funds. The rationale may have been that if the deposit rate was significantly lower, depositors would have been tempted to withdraw their

18 The regulations specified limits on the amount of loans by banks to affiliated companies, but were routinely ignored, both before and during the crisis. The banking law contains severe penalties, including imprisonment, for bank owners or managers who caused these limits to be exceeded. 
deposits and purchase foreign currency instead. But this method of artificially supporting the exchange rate came with a cost: the strategy amounted to paying a subsidy to people to induce them to continue to hold rupiah-denominated deposits. Since the government itself was by now the majority owner of the banking system, losses by the banks simply translated to bigger budget deficits. To put it differently, the banks were supposed to be restoring their capital adequacy ratios to $8 \%$ by the end of 2001 and, if they were not able to do so by retaining profits, then a further round of recapitalisation by the government would become necessary.

\section{Plans for deposit insurance and deeper capital markets}

It may be recalled that an intention of the initial LOI was to maintain the pre-crisis objective of requiring all banks to meet a minimum capital adequacy ratio of $12 \%$ by the end of 2001. In the January 2000 LOI the end-2001 objective became $8 \%$-without any discussion, and despite all the previous emphasis on the importance of strengthening the banks' balance sheets. This weakened capital adequacy standard was considered a precondition for the eventual establishment of a self-financed deposit insurance scheme by 2004 - the first mention of this matter since October 1997. It seems highly unlikely that this deadline will be met. In any case, the belief that a deposit insurance scheme will be capable of preventing future crises seems naive. If the new insurer turns out to be a government institution (as seems very likely), nothing will have been achieved - at least if the intention is to shift the risk of a banking collapse outside the public sector. ${ }^{19}$ On the other hand, given the magnitude of bank sector losses during the current crisis, it is hard to imagine that private sector insurers would be willing to underwrite what appear to be enormous risks except at premiums so high as to be politically unacceptable.

The intention to deepen bond and equity markets, allowing dependence on bank finance to be reduced, was reiterated in January 2000, although nothing had been achieved in this area since its mention in the first LOI. Widening the financing options available to companies is certainly a desirable objective, but nowhere in the LOIs is there any explanation for the heavy dependence on bank finance hitherto. Such an explanation can be found in the widespread perception that bank deposits

\footnotetext{
${ }_{19}$ A precedent for the government deceiving itself as to what is required to insure itself against banking losses is the loan insurance company, PT Askrindo, which it established in the 1970s to insure the state banks against non-repayment of subsidised loans given to small businesses (McLeod 1983: 85). Since the essential purpose of insurance is to spread risks, this was a total waste of resources: both the insurer and the insured belonged to the government, so the risks remained with the public sector.
} 
were implicitly guaranteed by the government - a perception that has proven well founded during the crisis, despite the government's strong announcements to the contrary prior to it. The key to raising the relative importance of bond and equity financing, therefore, would appear to be to find a way to remove the effective subsidy to bank finance that results from the implicit guarantee. A deposit insurance scheme, if run along market lines, would have the effect of forcing the banks to pay the cost of insurance cover for their depositors, thus reducing interest rates offered to depositors and increasing the interest rates charged to borrowers. This would have the desired effect of reducing the volume of savings intermediated through the banking system and correspondingly increasing the volume passing through bond and equity markets. Since the banks would be likely to resist the removal of this implicit subsidy to their operations, it would have been wise to point out in the LOIs that this is an implication of implementing a proper deposit guarantee scheme.

\section{IBRA's struggle to achieve}

The May 2000 LOI reported that IBRA's net asset recoveries totalled Rp 17.1 trillion in 1999/2000, and that the net cash recovery target for 2000 was Rp 18.9 trillion. These amounts are modest by comparison with the total volume of liquidity support given to the banks by Bank Indonesia (Rp 145 trillion), and they are extremely small relative to the total amount of recapitalisation bonds issued by the government (Rp 644 trillion). It was also reported that IBRA had launched a tender to outsource the work of restructuring about Rp 30 trillion of its commercial loans (from Rp 5 billion to $\operatorname{Rp} 50$ billion in value per obligor). ${ }^{20}$ This outsourcing was expected to be completed by end-June 2000, and the July 2000 LOI confirmed that this had been achieved. Once restructured, the loans were to be offered for auction. IBRA also intended to offer all its loans under Rp 5 billion for sale by open tender by September 2000. In the July 2000 LOI this had been postponed until the end of the year, and by the time of the August 2001 LOI, the deadline had become the end of 2001. In the April 2002 LOI, however, the government was still saying that it would launch a program to sell retail and (now outsourced) commercial loans by mid 2002.

By May 2000 it had been decided that eight banks that had been taken over would be merged into another, Bank Danamon, with the merged entity to be prepared for majority privatisation in 2001. Later, in the December 2001 LOI, IBRA announced plans to merge another five smaller banks which by then were under its full control. In all these cases, the authorities apparently came to the conclusion that the

20 'Obligor' is the term given to groups of debtors to IBRA that have common ownership. 
government would receive more from privatisation if it offered a larger merged entity for sale, rather than a number of smaller banks; the basis for this conclusion is not readily apparent, and has not been discussed in the LOIs. ${ }^{21}$ By implementing these mergers, any embarrassment the government might suffer by virtue of the revelation of large differences between their book values and the prices offered by private sector purchasers is avoided, of course, although this will become apparent eventually, when and if the merged entities are divested.

The July 2000 LOI stated that the privatisation of BCA and another of the large, formerly private banks, Bank Niaga, was to be completed by December 2000. In addition it noted that the government had finalised a plan to divest the remaining IBRA banks, and had submitted this plan to parliament in early June. As part of this strategy, it intended to launch the sale of a majority stake in Bank Danamon in July 2000, with completion of the sale by end-year, to be followed by the launch of the sale of a majority stake in another of the large, formerly private banks, Bank Lippo, by year-end. Not until the April 2002 LOI could it be reported that the sale of Bank BCA had been concluded, however. And although an attempt was made to sell Bank Niaga, the June 2002 LOI reported that the sale had not gone ahead because the bids were 'significantly below the market price'.

This was a nonsense, of course. The highest bid was the market price, by definition: the government-possibly reacting to some of its critics - was actually referring to the previously observed price for the bank's shares on the stock exchange, but this was virtually meaningless because only a negligibly small proportion of the shares was now owned by private sector investors. In any event, a 51\% stake in the bank was eventually sold in November 2002; there is nothing to suggest that the government obtained a better price than first offered (Jakarta Post 23 November 2002).

IBRA has continued to miss the targets for privatising banks. It only managed to sell a $10 \%$ stake in BCA in July 2001, and became bogged down in discussions with parliament regarding its intention to offer a further 51 percent for sale to a strategic partner by end-year. The intention was still to undertake a majority sale of Bank Niaga by December 2001. In the December 2001 LOI it was announced that the initial primary share issue for 30 percent of state-owned Bank Mandiri would be launched in the first quarter of 2002, and concluded in the second quarter. None of these aims was achieved. Frustration with IBRA's slow progress led the government in the

\footnotetext{
${ }^{21}$ For an alternative view on the policy of forced mergers, see Fane and McLeod (2002: 14-15).
} 
latter part of 2001 to transfer responsibility for IBRA to the Ministry of State-Owned Enterprises, thereby consolidating responsibility for all official asset sales within a single ministry.

\section{Summary}

In summary, the entire program for restructuring the banking system has had extremely disappointing results. At the outset, the intention was to abandon all state ownership of banks, but at the time of writing, not only has no state bank been divested, but the state has taken over a large number of private banks and closed scores of others, such that it is now by far the dominant owner of this sector. The rather belatedly recognised aim to minimise the losses to the government of the failure of the banking system has yielded dismal results, to which the response has been a continuing series of changes to the leadership of IBRA, to the control of IBRA by the government, and to IBRA's strategies for asset recovery, as well as to repeated protestations as to the government's serious intention to take strong legal action against recalcitrant bank owners if they were not more cooperative in cutting down the government's own losses. All to no avail.

\section{DEALING WITH SYSTEMIC BANK FAILURE}

By early 1998 it was beginning to become clear either that the banking system was in much worse condition than originally thought, or that it had deteriorated much more than anticipated. It was not sensible to persevere with the last resort lending approach because by now it was clear that the banks were not merely illiquid but were in many cases nearly, or actually, insolvent. The broad outlines of the approach adopted from January 1998 have already been discussed. Many banks were closed, and all of the large private banks were taken over by the government (some maintaining a minority shareholding on the part of the original owners). The original limited guarantee of deposits was replaced by a blanket guarantee over the full amount of the banks' liabilities. IBRA was established to act on behalf of the government as shareholder in the formerly private banks, to take over the most severely impaired category of non-performing loans from all the recapitalised banks (both state and private), and to take control of a huge portfolio of private sector assets that were handed over to secure the interest the government had acquired in the private banks by virtue of unpaid last resort loans and the blanket guarantee.

Did the blanket guarantee save the economy from collapse?

Policymakers within government and the IMF see it as a notable achievement of the program that the banking system has remained fully functional in its role as 
provider of the payments system. It is difficult to know exactly what damage would have been done to the economy if the payments system had been compromised: it is basically taken for granted that the cost would have been so great that any strategy to keep it fully operational would have involved a lesser cost. ${ }^{22}$ Now that we can see that the cost of the bank restructuring strategy is of the order of at least 40\% of GDP it seems worth at least raising the question of whether an interruption to the payments system would actually have been even more costly than this, but it is beyond the scope of this study to try to answer this question. Instead it may be helpful simply to outline an alternative approach that might have been followed in response to the threat of collapse of the banking system.

The initial approach was simply to guarantee deposits up to the value of $R p 20$ million per depositor in the sixteen small banks that were closed in November 1997. This policy had everything to do with distributional concerns, and nothing to do with keeping the payments mechanism intact. By declining to guarantee large deposits - which comprised a very large proportion of the total - the policymakers virtually ensured that there would be a rush to withdraw large deposits from many of the private banks that had not been closed, thus endangering the continued operations of the payments system. The size limit on the guarantee reflected a concern to look after the interests of those less well off, but even this aspect was ill considered. Individuals with bank deposits of the order of Rp 20 million certainly were not amongst Indonesia's poor, and by bailing out these depositors the government ensured that the genuinely poor would, in effect, be providing a subsidy to those in the middle classes. In short, the limited guarantee was poor policy on both efficiency and equity grounds.

As last resort lending began to run out of control the authorities realised their mistake, and the limited guarantee was modified to become a blanket guarantee. While this was successful in keeping the payments mechanism operational, it greatly compounded the inequity: Indonesia's poor - the vast majority of whom owned no bank deposits at all-would find themselves bailing out not only middle class individuals but also very wealthy people whose deposits were measured in millions of dollars. The obvious question is whether a different strategy could have been put in place so as to meet both equity and efficiency objectives.

22 'To have tried to force depositors to bear the costs of the banking failures could have led rapidly to the collapse of most, or all, banks in the country, turning Indonesia into a wasteland of financial intermediation and returning it to a cash or barter economy from which it would have taken many years to recover.' (Enoch et al. 2003). 
How to stop a system-wide bank run without a blanket guarantee

In thinking about alternative strategies that might have been employed to deal with the emerging banking crisis, we begin by recalling the basic source of Indonesia's macroeconomic problems: a reassessment on the part of investors of the risks of holding assets in Indonesia. One implication of this reassessment-resulting in a widespread perception that such risks were significantly greater than previously imagined - was that asset values would need to fall relative to asset values in the rest of the world. This insight leads naturally to the conclusion that the owners of bank deposits could have expected to suffer some losses, since their deposits played an important role in financing the creation of productive assets of all kinds. After all, the government had gone out of its way prior to the crisis to insist that it provided no guarantee of bank deposits, so it was under no obligation to guarantee deposits when the crisis struck.

A second important consideration in designing an appropriate bank restructuring strategy concerns the nature of a systemic bank run. A bank run occurs when a large enough number of depositors form the belief that the bank is probably insolvent. Those who can withdraw their funds early on will escape any loss, while others who leave their funds with the bank are likely to end up carrying all the bank's losses in excess of shareholders' equity. This behaviour is analogous to passengers rushing to be first into the lifeboats when a ship begins to sink, leaving others to fend for themselves as best they can. The more depositors become aware of the bank's problems, the quicker the bank's loss of liquidity, and the sooner it will be forced to disengage from the payments system. One policy response to this problem is simply not to allow deposit withdrawals to take place until some more permanent solution can be found, but the effect of this is to close down the payments system-as Argentina has recently found to its cost.

A better approach is suggested by everyday practice in the field of bankruptcy in the real sector. This approach involves putting all creditors' claims on hold and installing an administrator within the firm whose objective is to recover as much as possible for the creditors as a group, whether by keeping the firm going or by closing it down. Under this approach, creditors effectively replace the previous shareholders in the firm as claimants to the residual value of its assets. There is no reason why a very similar approach could not be used in the case of a systemic bank crisis. A small modification is necessary, however, in order to keep the payments mechanism functioning. This can be achieved by allowing depositors to withdraw a certain proportion of their deposits, while simultaneously converting the remainder to equity in the bank. This is best illustrated by a concrete example (Table 1). 
Table 1: Balance sheet of hypothetical insolvent bank

(Rp billion)

Initial condition (auditor's evaluation)

Assets

Loans
Liabilities

250

Deposits

Equity
340

$-90$

\section{After restructuring (some deposits converted to equity)}

Assets

Loans

\section{Liabilities}

250

Deposits

Equity $(16 \%$ CAR)
210

In this example it is assumed that the regulator has become aware that the bank is in trouble, most likely by observing a significant decline in the balance of its clearing account at the central bank, and perhaps also a significant increase in the rate the bank is having to pay to borrow on the interbank market. The regulator has then immediately imposed a freeze on new lending and commissioned an auditor to assess the value of the bank's assets and liabilities. For simplicity, these consist solely of loans and deposits, respectively. The true (realisable) value of loans is conservatively estimated to be 250 , while the value of deposits is 340 , implying negative equity of 90 . In other words, there is an implied aggregate loss to depositors of 90 . Suppose that the government decides that it wants banks to be capitalised to a capital adequacy ratio of $16 \% ; 23$ this implies that the required value of equity is 40 . Instead of injecting new equity itself, which has the regressive effect of shifting the loss from depositors to the general public, the government merely takes on the role of administrator of the insolvent bank, writing down the aggregate value of deposits by 130, and issuing shares to all the depositors in proportion to their share of total deposits. In the jargon of bankruptcy procedures this is known as a debt for equity swap.

23 This is double the international standard of $8 \%$, in line with the recommendation by Fane and McLeod (1999: 408-9) that banks in developing countries such as Indonesia should have to meet much stronger capital adequacy requirements than those in the more advanced economies, where uncertainty is less and the rule of law is more reliable. 
The impact, so far, is that the original shareholders have lost their equity investment in the bank, while depositors have lost a certain proportion of their investment in deposits (since the value of the shares they have just acquired is less than the value of deposits written off). The government - and therefore the general public - has lost nothing. The key point to note is that there is now no reason for a run on the bank. Depositors can no longer protect themselves against loss by being first to withdraw their funds. It is too late for that: the loss has already been shifted to them. ${ }^{24}$ Thus the integrity of the payments system is maintained. This is not to say, of course, that all depositors will see things this way, especially if there is a lack of trust on the part of the general public in the competence and integrity of the government in general and the prudential regulator in particular. If the run on the bank should continue, however, it is now safe for the central bank to undertake last resort lending, since the bank is now solvent (according to the conservative estimate of the regulator's auditors). ${ }^{25}$

The newly issued shares in this example have a theoretical value of 40 in aggregate. Depositor/shareholders are free to sell their new shares at whatever price the market determines, or to retain them, or indeed to increase their holdings; this decision will be driven by individual perceptions of the true value of the bank's assets (which is not necessarily the same as the auditor's estimate nor those of others in the market). It is not necessary that the bank be listed on the stock exchange. The bank would set up a registry of shareholdings that would be just like its records of individual deposits, except that rather than recording monetary amounts it would record numbers of shares held and transfers of ownership of shares between buyers and sellers. Outside individuals could also establish share accounts by purchasing shares from the initial depositor/ shareholders.

It is to be expected that some individuals or firms will be interested in the possibility of building up a large shareholding with a view to gaining management control of the bank. This is precisely what is required in order to get the bank back on its feet. To hasten this process, the government administrator would be empowered to issue new shares to such investors at prices equal to, or better than, the current market estimate of the true value of such shares.

\footnotetext{
24 This is analogous to the argument that the best way to bring currency speculation to a halt is simply to allow the price of foreign exchange to move to the level the speculators think is the market clearing level. Once this has happened, there is no prospect of a profit from speculation.

${ }^{25}$ Of course, the monetary impact of any such lending by the central bank would need to be sterilised.
} 
Keeping the payments system operational requires only that access to demand (cheque account) deposits be maintained. These accounted for only about $15 \%$ of total bank system deposits at the time Indonesia's crisis began, with time and savings deposits-used as investment instruments rather than for transactions purposes-accounting for the remainder. This suggests that the scheme just outlined could be implemented quite simply by giving demand deposits higher ranking than other types of bank liabilities in the event of banks having to be liquidated. That is, bank losses in excess of shareholders' funds would be borne by holders of time and savings deposits and other creditors of the bank, while the owners of demand deposits would only stand to lose if total losses exceeded the sum of all these other liability classes.

If the government wished to differentiate among time and savings deposits on the basis of size for equity reasons, it might choose to have 'small' time and savings deposits rank before 'large' deposits - but still behind demand deposits - in the case of insolvency of a bank. ${ }^{26}$ In any event, the owners of time and savings deposits who found themselves needing urgent access to funds in excess of the written-down amounts would have to sell their shares in the bank for whatever they could get for them, or perhaps borrow against the security of these shares.

Under the approach just outlined depositors would have been obliged to bear most of the burden of bank insolvencies - in other words, to share in the pain of the reduction in average asset values in Indonesia. The central bank would have had to bear the embarrassment brought about by the revelation of its failure to provide adequate prudential supervision of the banking system. But the 'innocent bystanders' - the tens of millions of relatively poor Indonesians who own no bank account deposits - would not have been left to suffer, as they have in reality, by virtue of having to share in amortising the cost the government incurred by providing the blanket guarantee.

This scheme not only avoids losses to the general public by ensuring that losses are borne by shareholders and depositors, but also avoids the shift of ownership of banks into the public sector that has been a major feature-and significant weakness - of the bank restructuring strategy in the IMF program. The government merely acts as an administrator on behalf of depositor/shareholders until such time as some entity assembles a dominant shareholding, at which time the government

\footnotetext{
26 This would have no implications for those members of the general public who owned no bank deposits at all.
} 
can withdraw from the scene. From then on management of the bank would simply be subject to the laws relating to corporate governance and to the prudential regulations for banks.

The mechanics of this scheme require the prudential regulator to assert some control over the operation of each bank as soon as it becomes aware of the likelihood that there is a liquidity and/or solvency problem. It should immediately place a temporary freeze on new lending and asset acquisitions of any significance, and on funds withdrawals by related parties; if the auditor's quick investigation reveals that the bank is indeed actually or nearly insolvent, this freeze would be extended indefinitely, pending resolution of the bank's equity position. It would probably be necessary to keep key managers in place, at least for the time being, but they should be subject to tight constraints as to actions they can take, with a view to guarding against all forms of asset stripping.

It is entirely possible, of course, that government administrators, supposedly working in the best interests of the depositor/shareholders, would actually act corruptly on behalf of other parties: for example, making risky loans on poor security, destroying the documentation for loans already provided by the bank, allowing defaulting borrowers to make deposit withdrawals, and so on. In order to guard against such dangers it would be essential to appoint individuals of very high repute-both Indonesians and foreigners - to serve in this role, just as is routinely done when administrators are appointed to run companies that become insolvent in other countries in the world of commerce outside banking. This problem also exists with the strategy the policymakers have actually chosen, of course, and is seemingly unavoidable.

Finally, bearing in mind the leverage the government has over owners who illegally make excessive loans to other affiliated companies in their conglomerates, the administrator appointed to each bank involved in the scheme could also be empowered to require these individuals to surrender various assets that could then be sold off to generate cash to repay these loans. The difference here from the actual strategy adopted by the government is that such assets would not be concentrated in a single holding company such as IBRA, but would be held in each of the banks individually.

\section{CONCLUSION}

Indonesia's crisis has been marked not only by severe recession but by an extraordinary redistribution of wealth in favour of the middle class and the very rich at the expense of the poor. This redistribution will be felt for years to come, partly as 
increases in taxes, and more importantly as reductions in subsidies that might otherwise be targeted to the poor through services such as education and health. It will also be manifested in reduced spending on infrastructure that would otherwise benefit the poor, through its beneficial impact on economic growth in general, and specifically on remote areas that would otherwise become better integrated with the national and international economy. The notion that similar occurrences will be avoided in the future by strengthening the implementation of prudential regulation and introducing some form of deposit insurance is entirely unconvincing in the context of a wobbly transition to democracy after years of autocratic rule by a powerful president, and the legacy of a weak and corrupt bureaucracy and legal system.

A superior approach to handling banking crises would be to treat them much the same as insolvencies of real sector enterprises, in which losses in excess of shareholders' equity are borne by creditors, not by 'innocent bystanders' - the general public. Under the scheme proposed here, most or all demand deposits would remain intact, which would allow the payments mechanism to continue to function. At the same time, existing shares would be cancelled, and a sufficient portion of other liabilities of the bank -including other forms of deposit-would be converted to equity so as to restore the bank's capital adequacy to a safe level. The fate of the bank would then be determined through market processes involving trading in these newly created shares. In other words, the decision as to whether to close banks or keep them going would be determined by markets rather than by bureaucrats, and the transfer of ownership of private banks to the public sector would be avoided. 


\section{References}

BPK-RI (2000). Badan Pemeriksa Keuangan-Republic of Indonesia, Siaran pers BPKRI Tentang Hasil Audit Investigasi Atas Penyaluran dan Penggunaan BLBI, [BPK-RI Press Release on the Findings of an Investigative Audit of the Disbursement and Utilisation of Bank Indonesia Liquidity Support], 4 August.

Enoch, Charles, Olivier Frécaut and Arto Kovanen (2003 forthcoming). 'Indonesia's Banking Crisis: What Happened and What Did We Learn?', Bulletin of Indonesian Economic Studies, 39 (1), April.

Fane, George and Ross H. McLeod (1999). 'Lessons for monetary and banking policies from the 1997-98 economic crises in Indonesia and Thailand', Journal of Asian Economics, 10 (3): 395-413.

(2002). 'Banking Collapse and Restructuring in Indonesia, 1997-2001', Cato Journal, 277-95.

Johnson, Colin (1998). 'Survey of Recent Developments', Bulletin of Indonesian Economic Studies, 34 (2), April: 3-60.

McKibbin, Warwick (1998). 'Internationally mobile capital and the global economy', in Ross H. McLeod and Ross Garnaut (eds) (1998), East Asia in Crisis: From being a miracle to needing one?, Routledge, London and New York.

McLeod, Ross H. (1983). 'Concessional Credit for Small Scale Enterprise: A Comment', Bulletin of Indonesian Economic Studies, 19 (1), April: 83-9.

(1997). "Some Comments on the Rupiah 'Crisis'", in Hal Hill and Thee Kian Wie (eds), Indonesia Assessment 1997, Indonesia's Technological Challenge, Institute of Southeast Asian Studies, Singapore: 96-103.

(2000a). 'Government-Business Relations in Soeharto's Indonesia', in Peter Drysdale (ed.), Reform and Recovery in East Asia: the role of the state and economic enterprise, Routledge, London and New York: 146-68.

(2000b). 'Soeharto's Indonesia: A Better Class of Corruption', Agenda, 7

(2): 99-112.

(2000c). 'Survey of Recent Developments', Bulletin of Indonesian Economic Studies, 36 (2), August: 5-40. 
(2002). 'Toward Improved Monetary Policy in Indonesia', Working Paper No. 10/2002, Division of Economics, Research School of Pacific and Asian Studies, Australian National University.

Soesastro, Hadi and M. Chatib Basri (1998). 'Survey of Recent Developments', Bulletin of Indonesian Economic Studies, 34 (1), April: 3-54. 